\title{
Physical Properties and Micro-structures of Heat-induced Gel of Some Mixed Protein Systems of Myosin B and Soy Protein CIF
}

\author{
Seiichi Haga*, Tomio Ohashi* and Kiyoshi Yamauchi* \\ * Faculty of Agriculture, Miyazaki University, 7710 Kumano, Miyazaki 889-21
}

\begin{abstract}
Effect of the mixing ratios of myosin B and soy protein CIF (Cold Insoluble Fraction) on the heat-induced gel formability was studied by the measurements of physical properties and scanning electron microscopy. The heat-induced gel formability of the protein system containing the fixed concentration of myosin B $(12 \mathrm{mg} / \mathrm{ml})$ increased with the increase of soy protein CIF content, and it became clear that the values of elastic modulus were especially affected by the concentration of soy protein CIF in the mixed protein systems. On the observation by scanning electron microscopy, the more quantity of soy protein CIF mixed with myosin B, the longer and wider frames of networks were formed. In the protein system containing the fixed concentration of soy protein CIF (50 $\mathrm{mg} / \mathrm{ml}$ ), the addition of myosin $\mathrm{B}$ caused increase of the values of breaking energy. The resulting micro-structure was composed of longer and more fibrous networks. In this manner the characteristic changes observed on micro-structures of the protein gels seem to correspond to the characteristic changes of physical properties of the gels.
\end{abstract}

It is well known that the binding quality and the water holding capacity of meat products are determined largely by the solubility and the extractability of meat proteins, which are influenced by a large number of factors. ${ }^{1}$ FuKazawa et al. ${ }^{2) 3}$ suggested in the early 1960 's that myofibrillar protein, myosin was an indispensable component of the binding property as well as the water holding capacity of meat and meat products. Many meat scientists( ${ }^{4)-18}$ ) have investigated these properties of meat and meat products by estimating the heat-induced gel formability of myofibrillar proteins.

On the other hand, non-meat protein products are currently used in a wide variety of processed meat products because of their nutritional values, some specific functionalities such as gel-strengthening ability, water holding capacity, etc. and greater yields of finished product. Soy protein CIF (Cold Insoluble Fraction), which mainly consists of $11 \mathrm{~S}$ and $7 \mathrm{~S}$ components having excellent physical properties, is especially useful as a non-meat protein products and its utilization tends to increase remarkably.

Under such situations, many studies ${ }^{19 \text { ) 25) }}$ have been conducted on the quality of meat products containing soy proteins. However little attention has so far been paid to the reasons why soy proteins may function as the gel-strengthening and/or water-binding agents at a molecular level. For instance, soy protein $\mathrm{CIF}$, which has many useful physical properties $^{26)}$ and is an excellent source of protein foods, denatures at a higher temperature than myofibrillar protein, myosin B (natural actomyosin) in skeletal muscle does. ${ }^{24) 27) ~ 30 \text { ) }}$ Therefore, it might be considered that soy protein have nothing to do with the binding property and/or the water holding capacity of meat products when treated below $80^{\circ} \mathrm{C}$. Because the optimum temperatures of myosin $\mathrm{B}$ and soy protein CIF for denaturation by thermal treatment are at $70^{\circ} \mathrm{C}$ and $100^{\circ} \mathrm{C}$, respectively. Nevertheless, our previous studies on the individual and mixed protein systems of myosin $B$ and soy protein CIF showed that firm and stable heat-induced gels of the mixture of them were obtained upon step-wise heating at $70^{\circ} \mathrm{C}$ and $100^{\circ} \mathrm{C}^{30) 81}$ ). On the other hand, PENG et $a l .{ }^{25)}$ showed by using Sepharose $6 \mathrm{~B}$ column chromatography together with SDS-PAGE electrophoresis that the interaction between myosin 
and soy $11 \mathrm{~S}$ protein did not occur at heating temperatures up to $85^{\circ} \mathrm{C}$. We $\mathrm{We}^{30}$ investigated the respective optimum conditions of myosin $B$ and soy protein CIF for forming the heatinduced gels, and showed that the former began to form gel on heating at $70^{\circ} \mathrm{C}$ for 30 min at a concentration of $12 \mathrm{mg} / \mathrm{ml}$, while the latter did upon heating at $100^{\circ} \mathrm{C}$ for $30 \mathrm{~min}$ at a concentration of $32 \mathrm{mg} / \mathrm{ml}$. In addition, we confirmed that when the both proteins were mixed together, a mechanically stable gel was formed under the conditions in which the individual proteins did not form gel. Thus, changes of the heat-induced gel formation on varying the mixing ratios of myosin $B$ and soy protein CIF still remain to be elucidated in detail. In order to obtain a clue to clarify the mechanism of heat-induced gel formation of the mixture of myosin B and soy protein CIF, this study examined the effects of varying the mixing ratios of the two proteins on physical properties and microstructures of the heatinduced gels in the mixed protein systems. Further, the relationships between the characteristics of microstructures of the gels and the statistical values of physical properties were investigated.

\section{Materials and Methods}

\section{Materials}

Rabbit muscles (back and leg muscles) were excised from carcasses just after slaughter and them immediately cooled in slushed ice. Thereafter all visible fat was removed, and the muscle was cut into pieces and ground through a plate of $2 \mathrm{~mm}$ mesh sieve. Myosin B was prepared according to the procedure of SzENTGYÖRGYI ${ }^{32)}$ and stored in a $50 \mathrm{mM}$ phosphate$0.6 \mathrm{M} \mathrm{KCl}$ buffer ( $\mathrm{pH} \mathrm{7.0)}$ at $4^{\circ} \mathrm{C}$. Soy protein CIF was prepared from defatted soy flour (Yoshinara Oil Mill Co. Ltd.) by the cryoprecipitation method ${ }^{33 / 34)}$ and stored in a 50 $\mathrm{mM}$ phosphate-0.6 M KCl buffer ( $\mathrm{pH} \mathrm{7.0)}$ ) at $4^{\circ} \mathrm{C}$. The two proteins were used within 2 days after preparation.

\section{Methods}

Two protein preparations were mixed at the designed concentrations with gently stirring overnight in an ice bath. Five milliliters of the resulting protein solution were placed in a tube (internal diameter: $15.56 \mathrm{~mm}$ ), which could be sealed with a teflon plug. The protein solutions in sealed tubes were heated first at $70^{\circ} \mathrm{C}$ for $4 \mathrm{~min}$ and then at $100^{\circ} \mathrm{C}$ for $30 \mathrm{~min}$ in a water bath controlled to $\pm 0.02^{\circ} \mathrm{C}$. The heated samples were cooled for $30 \mathrm{~min}$ in an ice bath after the heat treatment.

The physical properties and the solubility of the resulting protein gels were determined according to our previous methods ${ }^{\mathbf{3 5} \text {. }}$. The tube cortairing protein gel was applied to a rheometer (Sanwa-riken, JK-T 264 type) with an attached circular plate-plunger. Elastic modulus (stress/strain, dyre $/ \mathrm{cm}^{2}$ ) of the gel was calculated within proportional limit of stressstrain curve. Modulus of breaking elasticity (stress/strain, dyne $/ \mathrm{cm}^{2}$ ) and breaking energy (stress $\times$ strain, dyne $/ \mathrm{cm}^{2}$ ) were calculated at breaking strength of stress-strain curve. These physical parameters were calculated on the basis of load value $(\mathrm{g})$, cross section of the plunger $\left(0.5024 \mathrm{~cm}^{2}\right)$, length of gel $(2.8 \mathrm{~cm})$, penetration speed of plunger $(0.144 \mathrm{~cm} / \mathrm{sec})$ and chart speed of recorder $(18 \mathrm{~cm} / \mathrm{min})$. Changes in solubility were investigated by centrifuging at $35000 \times \mathrm{g}$ for $15 \mathrm{~min}$ with a Damon/IEC ultracentrifuge (Model B-60; rotor NO. 486). The solubility is expressed as protein concentration of the supernatant/protein concentration of the sample before centrifugation $\times 100(\%)$.

In addition, relationships between the sum of protein concentrations of the mixed protein systems and the heat-induced gel formability were statistically analysed.

Scanning electron microscopy was carried out according to the same manner as described previcusly ${ }^{36)}$. Gel pieces, $3 \times 3 \times 2 \mathrm{~mm}$, were immersed in $0.1 \mathrm{M}$ phosphate buffer ( $\mathrm{pH} 7.0$ ) containing $2.5 \%$ glutaraldehyde for $24 \mathrm{hr}$. at $4^{\circ} \mathrm{C}$. The fixed specimens were dipped in a $0.1 \mathrm{M}$ phosphate buffer ( $\mathrm{pH} \mathrm{7.0)}$ ) for $10 \mathrm{~min}$ and then post-fixed in the buffer with $1 \% \mathrm{OsO}_{4}$ for $5 \mathrm{hr}$. The fixed samples were rinsed three times with the phosphate buffer, each time with new buffer for $10 \mathrm{~min}$, and then dehydrated in graded alcohol series, transferred to similar isoamyl acetate series, and then 
dried in a Hitachi HCP-2 critical point drying apparatus (Hitachi Ltd., Tokyo). They were coated with gold in an ion sputtering apparatus (JEOL, type JFC-1100) and then examined and photographed with a JEOL Scanning Microscope (type JSM-35C) at an accelerating voltage of $15 \mathrm{kV}$.

\section{Results and Discussion}

Effect of soy protein CIF content on heatinduced gelation in the mixture of myosin $B$ and soy protein CIF

Our previous results ${ }^{30}$ showed that the mixture of myosin B and soy protein CIF produced the firmer and more stable gel as compared to that of the individual proteins. In the present study, a fixed concentration of myosin B (12 $\mathrm{mg} / \mathrm{ml}$ ), which was the minimum concentration for forming gel at $\mathrm{pH} 7.0$ and $70^{\circ} \mathrm{C}$, was heated with varying concentrations of soy pro-

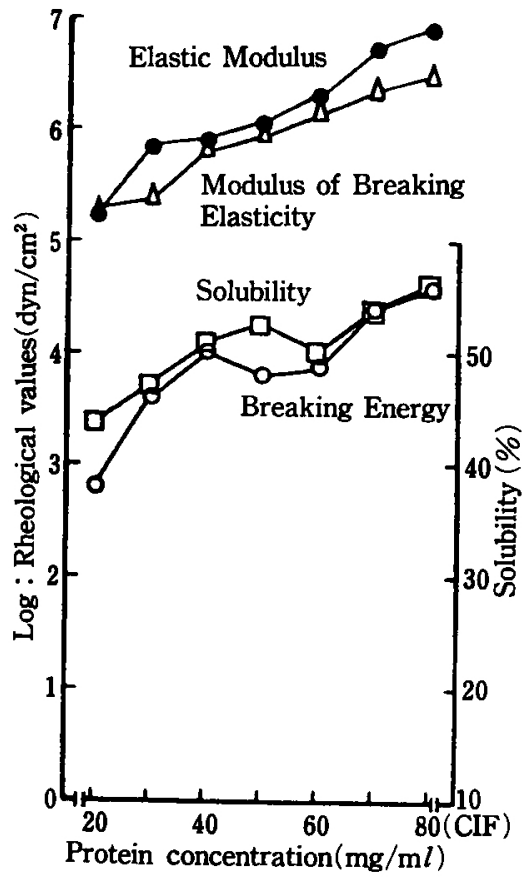

Fig. 1 Effect of varying concentrations of soy protein CIF of the mixture of myosin $\mathrm{B}$ and soy protein CIF on physical properties of the heat-induced gels at $\mathrm{pH}$ 7.0

myosin B: $12 \mathrm{mg} / \mathrm{ml}$ tein CIF from $0 \mathrm{mg} / \mathrm{ml}$ to $80 \mathrm{mg} / \mathrm{ml}$ at $10 \mathrm{mg}$ $/ \mathrm{m} l$ intervals. Subsequently, changes in physical properties (Elastic Modulus, EM; Breaking Energy, BE; Modulus of Breaking Elasticity, $\mathrm{MBE}$ ) and solubility (ratio of protein released from gels) as well as scanning electron microscopy of the resulting networks were examined. The results obtained are shown in Figs. 1, 2 and 3 , and Table 1.

The effect of varying soy protein CIF concentrations from $20 \mathrm{mg} / \mathrm{ml}$ to $80 \mathrm{mg} / \mathrm{ml}$ on physical properties of myosin B was inclined to increase with increasing the concentration of soy protein CIF (Fig. 1). Statistically, the coefficients of correlation between the protein concentrations and the values of EM, BE, MBE and solubility were $0.97,0.90,0.99$ and 0.92 , respectively and the results could be regarded as significant $(\mathrm{P}<0.01) \quad($ Table 1$)$.

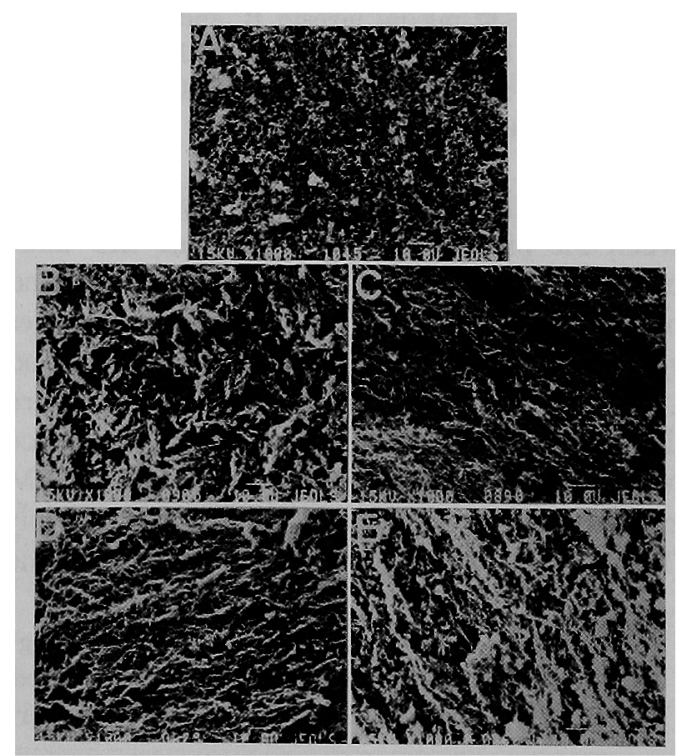

Fig. 2 Scanning electron micrographs of the mixtures of myosin $B$ and soy protein CIF after heat treatment

The mixed proteins were heated at $70^{\circ} \mathrm{C}$ for $4 \mathrm{~min}$ and then at $100^{\circ} \mathrm{C}$ for $30 \mathrm{~min}(\mathrm{pH} \mathrm{7.0}$ ). The mixing ratios of myosin $\mathrm{B}$ and soy protein CIF were as follows: A, $18 \mathrm{mg} / \mathrm{ml}$ myosin B alone; $B, 12 \mathrm{mg} / \mathrm{ml}$ myosin $B$ and $40 \mathrm{mg} / \mathrm{ml}$ CIF; C, $12 \mathrm{mg} / \mathrm{ml}$ myosin $\mathrm{B}$ and $60 \mathrm{mg} / \mathrm{ml}$ CIF; D, $12 \mathrm{mg} / \mathrm{ml}$ myosin $\mathrm{B}$ and $70 \mathrm{mg} / \mathrm{ml}$ $\mathrm{CIF}$; E, $12 \mathrm{mg} / \mathrm{ml}$ myosin $\mathrm{B}$ and $80 \mathrm{mg} / \mathrm{ml}$ CIF. Magnification: $\times 1000$. 


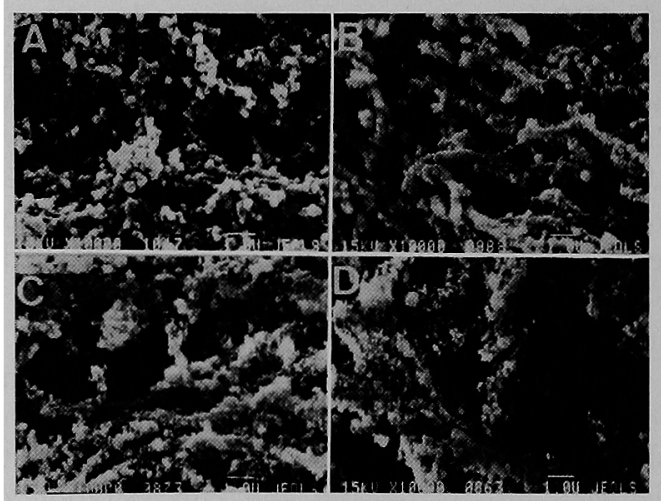

Fig. 3 Scanning electron micrographs of the mixtures of myosin B and soy protein CIF after heat treatment

The mixed proteins were heated at $70^{\circ} \mathrm{C}$ for $4 \mathrm{~min}$ and then at $100^{\circ} \mathrm{C}$ for $30 \mathrm{~min}(\mathrm{pH} \mathrm{7.0)}$. The mixing ratios of myosin $\mathrm{B}$ and soy protein $\mathrm{CIF}$ were as follows: $\mathrm{A}, 18 \mathrm{mg} / \mathrm{ml}$ myosin $\mathrm{B}$ alone; $\mathrm{B}, 12 \mathrm{mg} / \mathrm{ml}$ myosin $B$ and $60 \mathrm{mg} / \mathrm{ml}$ CIF; C, $12 \mathrm{mg} / \mathrm{ml}$ myosin $B$ and $70 \mathrm{mg} / \mathrm{ml}$ CIF; D, $12 \mathrm{mg} / \mathrm{ml}$ myosin $\mathrm{B}$ and $80 \mathrm{mg} / \mathrm{ml}$ CIF. Magnification: $\times 10000$.

The respective coefficients of regression between the protein concentrations of the mixtures of myosin B and soy protein CIF and the values of each of the physical properties were $3.54 \pm 0.05,3.38 \pm 0.09,2.94 \pm 0.03$ and $0.27 \pm 0.01$, indicating that the results were highly significant $(\mathrm{P}<0.01)$ (Table 1$)$. Since the ratios of contribution for predicting EM and $\mathrm{MBE}$ were $94.1 \%$ and $98.0 \%$, respectively (Table 1), it was clear that differences in the concentrations of soy protein CIF used were reflected in the values of elastic modulus in the mixed protein systems. In a solubility standing for the ratio of protein released from the gels, the coefficient of correlation was 0.92 and the figure was highly significant $(P<0.01)$.

Fig. 1 showed that solubilities tended to increase with increasing concentrations of added soy protein CIF. The result implied that added soy protein CIF could not be taken up into myosin B gel in proportion to the concentration of soy protein CIF. The change in the rheological value, therefore, does not always correspond to that in the amount of protein incorporating in a gel, but likely correspond to how the networks are formed. Hence, it may be reasonable to assume that the microstructure of gel could be an important contributor for the physical properties of gel. Some microstructures of the heat-induced gels formed from the mixed proteins were shown in Figs. 2 (at low magnification of $\times 1000$ ) and 3 (at high magnification of $\times 10000$ ). The more quantity of soy protein CIF mixed with myosin $B$, the longer and wider frame of networks was formed (Fig. 2, B-E, at magnification of $\times 1000$ ). In addition, photographs of the detailed observation (at magnification of $\times 10000$ ) were shown in Fig. 3(A). The heat-induced gel of myosin B consisted of frameworks of denatured proteins with globular projections (about $0.5 \mu \mathrm{m}$ in diameter) and their structures looked like a bead-type network. When the soy protein CIF was mixed with myosin B, it

Table 1 Coefficients of correlation $(r)$, regressions $(b)$ and standard errors (SE) and rates of contribution between the mixed protein concentrations of soy protein CIF and myosin $B$ and the physical properties of the gels

\begin{tabular}{|c|c|c|c|c|}
\hline Item & & $r$ & $b \pm \mathrm{SE}$ & $\begin{array}{c}\text { Rate of } \\
\text { contribution }\end{array}$ \\
\hline \multirow{4}{*}{ 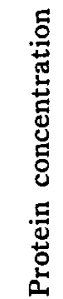 } & $\times$ Elastic modulus & $0.97^{* *}$ & $3.54 \pm 0.05^{* *}$ & 94.1 \\
\hline & $\times$ Breaking energy & $0.90 * *$ & $3.38 \pm 0.09 * *$ & 81.0 \\
\hline & $\times$ Modulus of breaking elasticity & $0.99 * *$ & $2.94 \pm 0.03^{* *}$ & 98.0 \\
\hline & $\times$ Solubility & $0.92 * *$ & $0.27 \pm 0.01^{* *}$ & 84.6 \\
\hline
\end{tabular}

$* * \mathrm{P}<0.01$ 
was observed that soy protein CIF bound continuously in contact with the surroundings of myosin B networks (Fig. 3, B-D). The networks of mixed protein gel became progressively wider with increasing the concentration of soy protein CIF. The apparent sizes of a thickness of networks were about $0.5 \mu \mathrm{m}, 0.7$ $\mu \mathrm{m}$ and $1.0 \mu \mathrm{m}$ at soy protein concentrations of $60 \mathrm{mg} / \mathrm{ml}, 70 \mathrm{mg} / \mathrm{ml}$ and $80 \mathrm{mg} / \mathrm{ml}$, respectively (Fig. 3, B-D). The formation of firm and tough gels was attributed to a binding such as to make wide the thickness of networks and these gels affected especially the values of elastic modulus.

Effect of myosin $B$ content on heat induced gelation in the mixture of myosin $B$ and soy protein CIF.

In this experiment, a fixed concentration of soy protein CIF $(50 \mathrm{mg} / \mathrm{ml})$, which was enough to form a relatively stable gel at $100^{\circ} \mathrm{C}$, was heated with the varying concentrations of myosin B from $12 \mathrm{mg} / \mathrm{ml}$ to $18 \mathrm{mg} / \mathrm{ml}$ at $2 \mathrm{mg} /$ $\mathrm{m} l$ intervals. Changes in the physical properties (EM, BE and MBE), solubility and microstructure of the gels were investigated, as have been done in the previous section. The results obtained are shown in Figs. 4 and 5, and Table 2.

The heat-induced gels of soy protein CIF $(50 \mathrm{mg} / \mathrm{ml})$ with myosin B $(12 \mathrm{mg} / \mathrm{ml})$ exhibited the higher rheological values in comparison with those without myosin B (Fig. 4). However, the further addition of myosin $B$ to 18 $\mathrm{mg} / \mathrm{m} l$ failed to improve the physical properties

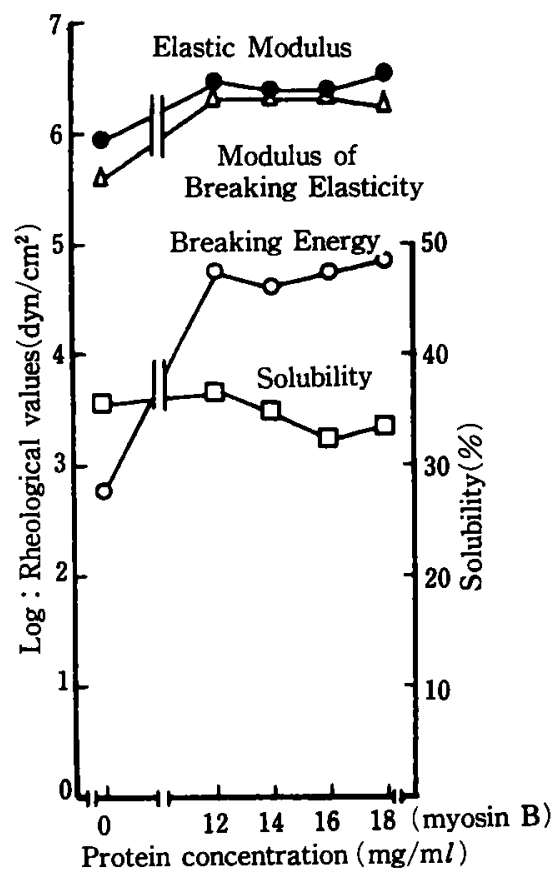

Fig. 4 Effect of varying concentrations of myosin $B$ of the mixture of myosin B and soy protein CIF on the physical properties of the heat-induced gels at $\mathrm{pH} 7.0$ Soy protein CIF : $50 \mathrm{mg} / \mathrm{ml}$

Table 2 Coefficients of correlation ( $r)$, regressions $(b)$ and standard errors (SE) and rates of contribution between the mixed protein concentrations of soy protein CIF and myosin $B$ and the physical properties of the gels

\begin{tabular}{|c|c|c|c|c|}
\hline Item & & $r$ & $b \pm \mathrm{SE}$ & $\begin{array}{l}\text { Rate of } \\
\text { contribution }\end{array}$ \\
\hline \multirow{8}{*}{ 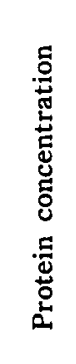 } & $\times$ Elastic modulus & 0.12 & $0.41 \pm 0.03$ & 1.4 \\
\hline & & $0.93^{*}$ & $4.13 \pm 0.01^{*}$ & 86.5 \\
\hline & $\times$ Breaking energy & 0.55 & $2.44 \pm 0.04$ & 30.3 \\
\hline & & $0.96 * *$ & $16.28 \pm 0.03^{*}$ & 92.2 \\
\hline & $\times$ Modulus of breaking elasticity & -0.19 & $-0.29 \pm 0.01$ & 3. 6 \\
\hline & & $0.94 *$ & $5.48 \pm 0.01^{*}$ & 88.4 \\
\hline & $\times$ Solubility & -0.92 & $-1.12 \pm 0.01$ & 84.6 \\
\hline & & -0.60 & $-0.25 \pm 0.00$ & 36.0 \\
\hline
\end{tabular}

Upper figures on each item are calculated without the soy protein and lower figures with the soy protein.

* $\mathrm{P}<0.05 ; * * \mathrm{P}<0.01$. 


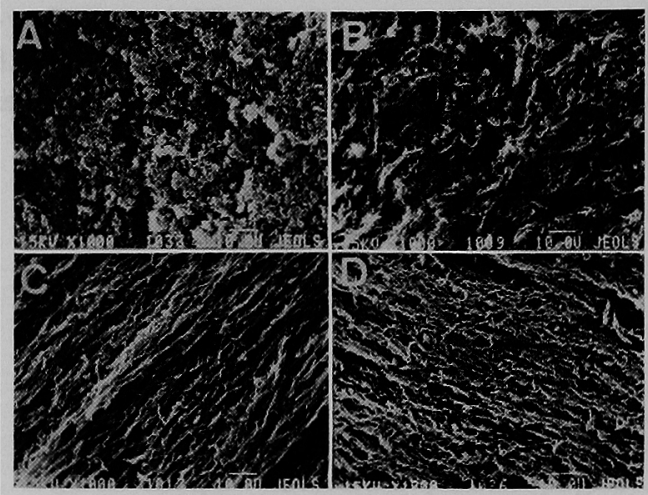

Fig. 5 Scanning electron micrographs of the mixtures of myosin B and soy protein CIF after heat treatment

The mixed proteins were heated at $70^{\circ} \mathrm{C}$ for $4 \mathrm{~min}$ and then at $100^{\circ} \mathrm{C}$ for $30 \mathrm{~min}(\mathrm{pH} \mathrm{7.0)}$. The mixing ratios of myosin $B$ and soy protein CIF were as follows: $\mathrm{A}, 50 \mathrm{mg} / \mathrm{ml} \mathrm{CIF}$ alone; $\mathrm{B}, 14 \mathrm{mg} / \mathrm{ml}$ myosin $\mathrm{B}$ and $50 \mathrm{mg} / \mathrm{ml} \mathrm{CIF} ; \mathrm{C}$, $16 \mathrm{mg} / \mathrm{ml}$ myosin $\mathrm{B}$ and $50 \mathrm{mg} / \mathrm{ml} \mathrm{CIF} ; \mathrm{D}$, $18 \mathrm{mg} / \mathrm{ml}$ myosin $\mathrm{B}$ and $50 \mathrm{mg} / \mathrm{ml} \mathrm{CIF}$. Magnification: $\times 1,000$.

of the system (Fig. 4). Thus, the coefficients of correlation between the protein concentrations and each of the rheological values were 0.12 (EM), 0.55 (BE) and -0.19 (MBE), and the results were not significant (Table 2). A similar trend was observed in the coefficient of correlation between the protein concentrations and the solubility (Fig. 4 and Table 2). On the other hand, in the system containing soy protein CIF alone, the coefficients of correlation between the protein cocentrations and the values of $\mathrm{EM}, \mathrm{BE}, \mathrm{MBE}$ and solubility were $0.93(\mathrm{P}<0.05), \quad 0.96 \quad(\mathrm{P}<0.01), 0.94$ $(\mathrm{P}<0.05)$ and -0.60 (not significant), respectively and were highly significant except for the coefficient of correlation of the solubility as shown in the parentheses (Table 2). The coefficients of regression between the two variation were also highly significant except for the solubility (Table 2). The result of breaking energy enabled its value to be predictable with a rate of contribution of $92.2 \%$, supporting that remarkable changes in breaking energy of the gels occurred with the addition of myosin B.

Micro-structures of the gels were observed with a scanning electron microscope $(\times 1000)$. As shown in Fig. 5, in the microstructures of soy protein CIF gels, it was observed that irregular and sponge-like structures consisted of some aggregates, whereas in the microstructures of the mixture of soy protein CIF and myosin $B$ the formation of longer and more fibrous networks was observed with increasing concentrations of myosin $B$. In this manner myosin B could transform an irregular and sponge-like microstructure of soy protein CIF into a fibrous structure. The results of this study suggested that myosin B networks might be a dominant factor involved in forming the frames of microstructures which were observed in the mixture of myosin B and soy protein CIF and that the gels of soy protein CIF, which were composed of more dense networks (less than $1 \mu \mathrm{m}$ in poresize) ${ }^{19}$ ), adhered to the surroundings of myosin $B$ networks and participated in the formation of the firm and tough protein gels. Characteristic changes in microstructure of the heat-induced gels depend on the mixing ratios of myosin $B$ and soy protein CIF and are accompanied by changes in the rheological values of the gels. The results obtained in the present study will further provide some meaningful suggestions for the improvement in the quality of meat products containing soy protein.

Acknowledgement: The authors are very greateful to Dr. T. Fukazawa and Dr. T. Ito, Kyushu Univ., for the valuable criticism and many suggestions during this work. The authors also thank Yoshihara Oil Mill Co., Ltd. for providing defatted soy meal.

\section{References}

1) Schmidt, G. R. and Trout, G. R.: Meat Science and Technology International Symposium Proceedings, Lincoln, Nebraska, Nov., p. 265 1982.

2) Fukazawa, T., Hashimoto, Y. and Yasui, T.: J. Food Sci., 26, 541 (1961).

3) Fukazawa, T., Hashimoto, Y. and Yasui, T.: J. Food Sci., 26, 550 (1961).

4) Samejima, K., Hashimoto, Y., Yasui, T. and Fukazawa, T.: J. Food Sci., 34, 242 (1969).

5) Sato, Y. and Nakayama, T.: J. Texture Stud., 1, 309 (1970).

6) Nakayama, T. and Sato, Y.: J. Texture 
Stud., 2, 75 (1971).

7) Deng, J., Toledo, R. T. and Lillard, D. A.: J. Food Sci., 41, 273 (1976).

8) Yasui, T., Ishioroshi, M., Nakano, H. and SAMEjIMA, K.: J. Food Sci., 44, 1201 (1979).

9) Ishroroshi, M., Samejima, $K$. and Yasui, T.: J. Food Sci., 44, 1280 (1979).

10) Siegel, D. G, and Schmidt, G. R.: J. Food Sci., 44, 1686 (1979).

11) Turner, R. H., Jones, P. N. and MacFarlane, J. J.: J. Food Sci., 44, 1443 (1979).

12) Ishioroshi, M., Samejima, K., Arie, Y. and Yasur, T.: Agric. Biol. Chem., 44, 2185 (1980).

13) SAmejima, K., Ishioroshi, M. and Yasui, T.: J. Food Sci., 46, 1412 (1981).

14) Schmidt, G. R., Mawson, R.F. and Siegel, D. G.: Food Technol., 35, 235 (1981).

15) Acton, J.C., Hanna, M. A. and Satterlee, L. S.: J. Food Biochem., 5, 101 (1981).

16) Ishioroshi, M., Samejima, $K$. and Yasui, T.: J. Food Sci., 47, 114 (1982).

17) Ishioroshi, M., Samejima, $K$. and Yasur, T.: Agric. Biol. Chem., 47, 2809 (1983).

18) Samejima, K., Yamauchi, H., Asghar, A. and Yasui, T.: Agric. Biol. Chem., 48, 2225 (1984).

19) Yamamoto, K., Fukazawa, T. and Yasui, T.: Mem. Fac. Agric., Hokkaido Univ. Jpn., 9, 116 (1973).

20) Yamamoto, K., Kajiyama, Y. and Samejima, K.: J. Coll. Dairy. Jpn., 7, 39 (1977).

21) King, N. L.: J. Agric. Food Chem., 25, 166 (1977).

22) Shiga, K.: J. Fac. Appl. Biol. Sci., Hiroshima Univ. Jpn., 19, 183 (1980).

23) Furukawa, T., Koyama, S. and Ohta, S.: Nippon Shokuhin Kogyo Gakkaishi, 29, 208 (1982).

24) Peng, I. C., Dayton, W. R., Quass, D. W. and Allen, C. E.: J. Food Sci., 47, 1976 (1982).

25) Peng, I. C., Dayton, W. R., Quass, D. W. and Allen, C. E.: J. Food Sci., 47, 1984 (1982).

26) Wolf, W. J.: J. Agric. Food Chem., 18, 969 (1970).

27) Hashizume, K., Nakamura, N. and Watanabe, T.: Agric. Biol. Chem., 39, 1339 (1975).

28) Haga, S., Ohashi, T. and Fukazawa, T.: Bull. Fac. Agric. Miyazaki Univ. Jpn., 21,
81 (1974).

29) HaGA, S. and OHashi, T.: Nippon Shokuhin Kogyo Gakkaishi, 24, 243 (1977).

30) Haga, S. and Ohashi, T.: Nippon Shokuhtn Kogyo Gakkaishi, 25, 226 (1978).

31) HaGa, S. and OHAshi, T.: Nippon Shokuhin Kogyo Gakkaishi, 25, 231 (1978).

32) Szent-Györgyi, A. "Chem. Muscular Contraction", 2nd Ed., Academic Press Inc., New York, N. Y., 1951, p. 72.

33) Briggs, D. R. and Wolf, W. J.: Arch Biophys, 72, 127 (1957).

34) Eldridge, A. C. and Wolf, W. J.: Cereal Chem., 44, 645 (1967).

35) Haga, S. and Ohashi, T.: Nippon Shokuhin Kogyo Gakkaishi, 26, 422 (1979).

36) Haga, S. and Ohashi, T.: Agric. Biol. Chem., 48, 1001 (1984).

(Received Sep. 4, 1985)

\section{ミオシン B と大豆蛋白質 CIF 共存系加熱ゲルの 物性と微細構造}

\section{芳賀聖一 * 大橋登美男 ${ }^{*} \cdot$ 山内 清 ${ }^{*}$}

* 宮崎大学農学部（T 889-21 宮崎市大字熊野 7710)

ミオシンBと大豆蛋白質 CIF (Cold Insoluble Fraction）共存系の加熱ゲル形成について，その共存割合の 影響を物理的特性の湘定や走査型電子顕微鏡観察によっ て調べた. $12 \mathrm{mg} / \mathrm{m} l$ ミオシン Bに共存させる大豆蛋白 質 CIF の割合を増していくと，その加熱ゲル形成能も 増し，特に，弾性率の値に反映することが明らかになっ た. 走查型電子顕微鏡観察によるとミオシンBに共存さ せる大豆蛋白質量が多くなるにつれて，より長くまた， より広い骨格をもった網目椣造が形成された。また，50 $\mathrm{mg} / \mathrm{m} l$ 大豆蛋白質 CIF にミオシンBを共存させると, 破断エネルギーの值が増加主る加熱ゲルが形成された. その微細構造は，より長く線維状に伸びた網目構造で構 成されていた．このように，蛋白質ゲルの微細構造に観 察された特徴的変化は, ゲルの物理的特性の变化之対応 するものであった. 